BARBARA JANKOWIAK

Uniwersytet im. Adama Mickiewicza

$w$ Poznaniu

\title{
KOMPETENCJE SOCJOTERAPEUTY - WYBRANE ZAGADNIENIA
}

\begin{abstract}
Jankowiak Barbara, Kompetencje socjoterapeuty - wybrane zagadnienia [The Sociotheraphist's Competences - Selected Issues]. Studia Edukacyjne nr 37, 2015, Poznań 2015, pp. 289-311. Adam Mickiewicz University Press. ISBN 978-83-232-2967-4. ISSN 1233-6688. DOI: 10.14746/se.2015.37.17

The aim of this article is to analyze the competences of sociotherapists, which make it possible to help members of groups. Sociotherapy consists in psycho-pedagogic group help for children and adolescents from risk groups or for those who have problems functioning in society. Five important basic competence areas have been signaled and described: 1) psycho-pedagogic, 2) diagnostic, 3) group work, 4) self-development, 5) moral. Describing these competences enables one to analyze various aspects of a sociotherapist's work.
\end{abstract}

Key words: sociotherapists, sociotheraphy, competences

\section{Pojęcie kompetencji zawodowych w kontekście pomocy psychologiczno-pedagogicznej dla dzieci i młodzieży}

Socjoterapia to forma pomocy psychopedagogicznej ukierunkowana na dzieci i młodzież z grup ryzyka lub/i przejawiających zaburzenia w funkcjonowaniu psychospołecznym polegająca na intencjonalnym uruchamianiu czynników pomocowych w celu kompensacji potencjalnych deficytów rozwoju społecznego i zapobieganiu kształtowania się zaburzeń uczestników grupy ${ }^{1}$. Socjoterapia jest więc oddziaływaniem pomocowym, podczas które-

${ }^{1}$ B. Jankowiak, E. Soroko, Socjoterapia a inne formy pomocy psychologiczno-pedagogicznej, [w:] Socjoterapia jako forma pomocy psychologiczno-pedagogicznej. Teoria i praktyka, red. B. Jankowiak, Poznań 2013. 
go przeplatają się zarówno oddziaływania psychologiczne i terapeutyczne, jak również pedagogiczne i wychowawcze. Dlatego, kompetencje socjoterapeutów będą rozpatrywane zarówno w kontekście interwencji edukacyjnowychowawczych, wspierania rozwoju uczestników grup, jak i elementów terapii grupowej, gdyż wszystkie mają miejsce $\mathrm{w}$ pracy $\mathrm{z}$ grupą dzieci i młodzieżą w socjoterapii.

Według W. Strykowskiego, pojęcie kompetencji używane jest w dwóch znaczeniach: po pierwsze, kompetencje utożsamiane są z kwalifikacjami, po drugie, termin kompetencje oznacza zakres uprawnień2. Kompetencja to, według O.H. Jenkinsa, zdolność i gotowość do wykonywania zadań na określonym poziomie, a według D. Fontany wyuczalna umiejętność robienia rzeczy dobrze, to sprawności niezbędne do radzenia sobie z problemami ${ }^{3}$. Kompetencje mają charakter podmiotowy - są własnością określonej osoby. Szczególnym ich atrybutem jest dynamika ujawniająca się $\mathrm{w}$ działaniu, w relacji człowieka z rzeczywistością 4 .

Zdaniem M. Czerepaniak-Walczak ${ }^{5}$, kompetencja odnosi się zawsze do podmiotu (określonej osoby) i jest szczególną właściwością wyrażającą się $\mathrm{w}$ demonstrowaniu, na wyznaczonym przez społeczne standardy poziomie, umiejętności adekwatnego zachowania się oraz w świadomości potrzeby i konsekwencji takiego właśnie zachowania się oraz $\mathrm{w}$ przyjmowaniu na siebie odpowiedzialności za nie. Jest to dyspozycja osiągana poprzez wyuczenie, uświadamiana przez człowieka, możliwa do zaobserwowania przez innych i powtarzana. Kompetencja jest harmonijną kompozycją wiedzy, sprawności, rozumienia oraz pragnienia - „pragnę to zrobić dobrze" 6 . W niniejszym artykule kompetencje socjoterapeutów omawiane będą pod względem kwalifikacji niezbędnych do efektywnego wykonywania zawodu.

Socjoterapeuta podczas pracy z dziećmi i młodzieżą realizuje cele terapeutyczne, rozwojowe i edukacyjne ${ }^{7}$. Jego kompetencje powinny więc umożliwić osiągnięcie tych celów podczas zajęć grupowych.

W literaturze przedmiotu bardzo wiele miejsca poświęca się analizie kompetencji pedagogicznych - mogących mieć znaczenie w realizacji celów edukacyjnych w socjoterapii. Na przykład W. Strykowski wyróżnia następujące obszary kompetencji ważne dla zawodu nauczyciela: 1) kompetencje

2 W. Strykowski, Kompetencje wspótczesnego nauczyciela, Neodidagmata, 2005, 27/28, s. 15-28.

3 Za: M. Czerepaniak-Walczak, Aspekty i źródła profesjonalnej refleksji nauczyciela, Toruń 1997.

${ }^{4}$ W. Strykowski, Kompetencje wspótczesnego nauczyciela, s. 15-28.

${ }^{5}$ M. Czerepaniak-Walczak, Między dostosowaniem a zmiana. Elementy emancypacyjnej teorii edukacji, Szczecin 1995, s. 135-137.

${ }^{6}$ M. Czerepaniak-Walczak, Aspekty i źródta profesjonalnej refleksji nauczyciela, s. 88.

7 Sobolewska, 1993; za: J. Jagieła, Socjoterapia w szkole. Krótki poradnik psychologiczny, Kraków 2007, s. 25-26. 
merytoryczne (rzeczowe) - wiążą się one z dobrym opanowaniem i zrozumieniem przez nauczyciela materiału stanowiącego treść nauczania; 2) kompetencje psychologiczno-pedagogiczne - dotyczą one wiedzy i umiejętności z zakresu różnych działów współczesnej psychologii i pedagogiki oraz pozwalają nauczycielowi na skuteczne działania diagnostyczne i wychowawcze; 3) kompetencje diagnostyczne - związane z poznawaniem uczniów i ich środowiska; 4) kompetencje w dziedzinie planowania i projektowania - dotyczą opracowywania programów, planów i projektów działań dydaktycznych oraz wychowawczych; 5) kompetencje dydaktycznometodyczne - tworzy je wiedza na temat istoty, zasad i metod realizacji procesu kształcenia; 6) kompetencje komunikacyjne - ich istota zawiera się w umiejętności efektywnego nadawania i odbierania komunikatów; 7) kompetencje medialne i techniczne - związane są z nowoczesną techniką informatyczną i jej zastosowaniem $\mathrm{w}$ procesie kształcenia; 8) kompetencje związane z kontrolą i oceną osiągnięć uczniów oraz jakościowym pomiarem pracy szkoły; 9) kompetencje dotyczące projektowania i oceny programów oraz podręczników szkolnych; 10) kompetencje autoedukacyjne - związane $\mathrm{z}$ rozwojem zawodowym 8 .

Odbiorcy oddziaływań socjoterapeutycznych to często dzieci i młodzież zagrożona niedostosowaniem społecznym (korzystająca $\mathrm{z}$ socjoterapii w szkołach lub innych placówkach opiekuńczo-wychowawczych) lub doświadczająca już konsekwencji owego niedostosowania. Młodzież z tej drugiej grupy może przebywać w placówkach, w których socjoterapia jest działaniem pomocowym będącym składową oddziaływań resocjalizacyjnych. Zdaniem Z. Bartkowicza ${ }^{9}$, kompetencje wychowawcze istotne $\mathrm{w}$ pracy z podopiecznym niedostosowanym społecznie są zbieżne z kompetencjami nauczycielskimi. Autor ten wymienia sześć obszarów kompetencji: psychologiczno-pedagogiczne, diagnostyczne, w zakresie planowania i projektowania, komunikacyjne, autoedukacyjne, moralne.

M.S. i G. Coreyowie pisząc o kompetencjach zawodowych wszystkich specjalistów prowadzących grupy (zarówno robocze, treningowe, jak i psychoedukacyjne oraz psychoterapeutyczne), zwracają uwagę na skład osobowy grupy - tzn. jakiego typu osoby, np. w jakim wieku, są członkami grupy. Osoba kompetentna powinna znać specyfikę pracy z tymi odbiorcami.

8 W. Strykowski, Szkoła wspótczesna i zachodzace w niej procesy, [w:] Kompetencje nauczyciela szkoły wspótczesnej, red. W. Strykowski, J. Strykowska, J. Pielachowski, Poznań 2007.

9 Z. Bartkowicz, Ksztattowanie świadomości aksjologicznej pedagogów resocjalizacyjnych, [w:] Powinności i kompetencje w wychowaniu osób niedostosowanych spotecznie, red. Z. Bartkowicz, A. Węgliński, A. Lewicka, Lublin 2010, s. 42. 
Wprost o kompetencjach koniecznych w socjoterapii pisze J. Jagiełła. Autor ten podaje ${ }^{10}$, że o kompetencjach socjoterapeuty świadczą następujące elementy: 1) wykształcenie i kwalifikacje (ukończone studia z psychologii, pedagogiki, socjologii lub innej bardzo zbliżonej do tych dziedzin dyscypliny, uzupełnione kilkuletnim szkoleniem w zakresie terapii); 2) cechy osobiste i umiejętności; 3) paradygmat pracy i stosowane metody; 4) superwizja; 5) terapia własna; 6) postawa etyczna. Zostaną one omówione w dalszej części pracy.

J. Strykowska uznaje, że kompetencje socjoterapeuty powinny stanowić połączenie typu osobowości, określonej postawy wobec socjoterapii oraz wiedzy i umiejętności dobrego terapeuty grupowego, wychowawcy i opiekuna ${ }^{11}$.

Przytoczone przykłady kompetencji mogących mieć znaczenie $\mathrm{w}$ pracy socjoterapeutycznej stanowią bardzo szeroką i różnorodną grupę. W dalszej części rozprawy dokonano analizy najczęściej pojawiających się w literaturze obszarów kompetencji socjoterapeutów.

\section{Wybrane aspekty profilu osobowości oraz postaw zawodowych socjoterapeutów}

Analiza literatury przedmiotu $\mathrm{w}$ odniesieniu do kompetencji zawodowych pedagogów, terapeutów i trenerów obfituje w opisy cech osobowych oraz postaw przyczyniających się do efektywności podejmowania zadań zawodowych. Definiowanie kompetencji zawodowych przez określanie cech osobowości sprzyjających skuteczności zawodowej jest niewątpliwie ważną wskazówką dla osób zastanawiających się nad wyborem takiej ścieżki zawodowej, stawiających sobie pytanie, czy ich zasoby osobiste są zbieżne z profilem osoby profesjonalnie zajmującej się socjoterapią. Jednocześnie jest jednak mało użyteczne ze względu na niewielkie możliwości zmiany określonych cech i ich kształtowania podczas indywidualnej drogi edukacyjnej. Wydaje się, że przedstawienie określonych pożądanych postaw daje znacznie większy potencjał $\mathrm{w}$ zakresie ustalania celów szkolenia $\mathrm{z}$ socjoterapii oraz samorozwoju socjoterapeutów.

Na przykład, J. Jagieła12 pisze o cechach osobowości kompetentnego socjoterapeuty, podając jednak głównie określone postawy socjoterapeutów wobec uczestników grup oraz własnej roli zawodowej. Autor ten jako istot-

\footnotetext{
${ }^{10}$ J. Jagieła, Socjoterapia w szkole.

${ }^{11}$ J. Strykowska, Kompetencje socjoterapeutyczne w pracy pedagogicznej, Neodidagmata, 2011, $31 / 32$.

$12 \mathrm{~J}$. Jagieła, Socjoterapia w szkole.
} 
ne wymienia: umiejętność nawiązywania kontaktu, zdolność do efektywnego komunikowania się, tolerancyjność, gotowość do udzielania pomocy, posiadanie dobrej woli i troski, gotowość do ujawniania własnych emocji, dawanie dobrego przykładu, otwartość, nieprzyjmowanie postawy obronnej wobec ataków, samoświadomość, poczucie humoru, dobrą kondycję fizyczną i wewnętrzną siłę.

J. Strykowska13 uznaje, że profil osobowości socjoterapeuty powinien cechować się chęcią do ciągłego pogłębiania swojej samoświadomości. Najlepiej, gdyby to była osobowość: uporządkowana, świadoma, ciekawa, intrygująca, tolerancyjna, odważna, odpowiedzialna, empatyczna i konsekwentna. Ważna jest gotowość do udzielania pomocy, wypływająca z dobrej woli i troski o drugiego człowieka. Wskazana jest otwartość i tolerancyjność wobec różnego rodzaju postaw młodych ludzi. Autorka wymienia także odwagę i poczucie humoru. Natomiast pożądaną postawą wobec socjoterapii jest zaangażowanie i jednocześnie dystans wobec trudności tych, wśród których terapeuta pracuje.

R. Opora ${ }^{14}$ wymienia cechy wychowawcy osób niedostosowanych społecznie wpływające na jego skuteczność. Są to: wiarygodność, zaufanie, zaangażowanie, optymizm pedagogiczny (aby nikogo nie przekreślać z góry), konsekwencja, cierpliwość, poczucie humoru, kreatywność i elastyczność, energia.

M.S. Corey i G. Corey ${ }^{15}$ opisując cechy osobowości skutecznego trenera lub terapeuty grupowego, wymieniają określone cechy i postawy: odwage przejawiającą się w gotowości do: odsłaniania własnej słabości i przyznawania się do błędów, konfrontacji z innymi, przy jednoczesnym „byciu” z nimi $\mathrm{w}$ trakcie pracy nad konfliktem, działania w zgodzie z własnymi przekonaniami, emocjonalnej reakcji na sprawy uczestników, badania i analizowania własnego życia, bycia bezpośrednim i szczerym wobec uczestników, wyrażania wobec uczestników własnych obaw i oczekiwań związanych z procesem grupowym; gotowość do modelowania - dawania przykładu; emocjonalną obecność w grupie; dobrą wolę i troskę - zainteresowanie dobrem innych, wiarę w proces grupowy; otwartość wobec siebie samego i wobec uczestników; pogłębianie świadomości swojego zaplecza kulturowego gotowość do przyjęcia odmienności; nieprzyjmowanie postawy obronnej podczas ataków; moc osobistą - zaufanie do siebie i charyzmę; wytrzymałość i odporność; gotowość do poszukiwania nowych doświadczeń; samoświadomość; poczucie humoru; pomysłowość; osobiste zaangażowanie.

\footnotetext{
${ }^{13}$ J. Strykowska, Kompetencje socjoterapeutyczne.

${ }_{14}$ R. Opora, Resocjalizacja: wychowanie i psychokorekcja nieletnich nie dostosowanych społecznie, Kraków 2010, s. 63-72.

${ }^{15}$ M.S. Corey, G. Corey, Grupy. Metody grupowej pomocy psychologicznej, Warszawa 2002.
} 
Kolejnych wskazówek dotyczących pożądanej postawy zawodowej dostarcza towarzystwo naukowe zrzeszające socjoterapeutów. Sekcja socjoterapii Polskiego Towarzystwa Psychologicznego opracowała standardy kwalifikacji zawodowych. Zgodnie $\mathrm{z}$ nimi, w obszarze cech i postaw znalazły się: świadomość swojej hierarchii wartości, świadomość swoich mocnych i słabych stron, gotowość do pracy zespołowej, gotowość do samorozwoju i doskonalenia, zaangażowanie $\mathrm{w}$ pracę i sprawy dzieci, szacunek wobec ludzi, poszanowanie ich godności, zrównoważenie emocjonalne, brak uprzedzeń rasowych, etnicznych, wiekowych, kulturowych i religijnych, otwartość wynikająca z wewnętrznej integracji osobowości, empatia, kreatywność i elastyczność w myśleniu, spójność myśli słów i zachowañ ${ }^{16}$.

Podkreślana jest także postawa etyczna socjoterapeutów. Zdaniem J. Jagieły wyraża się ona poprzez: dyskrecję, szacunek wobec prywatności, ochronę uczestników przed przemocą werbalną i fizyczną, ustalenie uczciwych reguł zawierania kontraktu z dziećmi i ich rodzicami oraz świadomość własnych kompetencji i ograniczeń zawodowych ${ }^{17}$.

Zdaniem K. Waszyńskiej, w pracy socjoterapeutycznej prowadzący jest na różnych etapach relacji pomagania źródłem, narzędziem i przedmiotem zmian. Pracuje w dużej mierze sobą: swoimi zasobami, umiejętnościami, opierając się na wiedzy i doświadczeniu. Dlatego tak ważne są jego kompetencje, samoświadomość, otwartość i chęć do oglądania swej pracy z innymi specjalistami, a także gotowość do uczenia się i poszerzania swego warsztatu pracy $^{18}$.

\section{Umiejętności i kompetencje interpersonalne w pracy socjoterapeutycznej}

Analiza umiejętności, które autorzy wymieniają jako istotne w pracy socjoterapeutycznej skłania do wyróżnienia dwóch uzupełniających się grup. W skład pierwszej wchodzą takie umiejętności, które ważne są w każdym rodzaju pomocy psychologiczno-pedagogicznej (a właściwie w każdej niemal pracy z drugim człowiekiem). Są to takie umiejętności prowadzenia rozmowy, jak np. parafrazowanie, klaryfikowanie czy kierowanie. Drugą stanowią umiejętności odnoszące się do kwestii "grupowości" tej formy pomocy. Do tej grupy można zaliczyć na przykład znajdowanie wspólnych

16 http://www.ptp.org.pl/modules.php?name=News\&file=article\&sid=394, [dostęp: 28.03.2015].

$17 \mathrm{~J}$. Jagieła, Socjoterapia w szkole.

${ }^{18}$ K. Waszyńska, Socjoterapeuta: osoba i specjalista. Kompetencje i kwalifikacje socjoterapeuty, [w:] Socjoterapia jako forma pomocy psychologiczno-pedagogicznej. 
mianowników między uczestnikami, blokowanie niewłaściwych zachowań w grupie, czy umiejętność rozpoczynania i kończenia zajęć.

J. Jagieła do umiejętności profesjonalnych socjoterapeutów zaliczył: umiejętności aktywnego słuchania, empatię, powtarzanie, parafrazowanie, klaryfikowanie, podsumowywanie, dostarczanie własnych ocen, interpretowanie, konfrontowanie, akcentuacją (czyli wyrażanie dostrzeganych przez terapeutę częstych powtórzeń przez dziecko pewnych tematów, wariantów danej sytuacji, osób, wątków), blokowanie niewłaściwych zachowań, zadawanie pytań, znajdowanie wspólnych mianowników, bycie konkretnym, pomoc w selekcjonowaniu, udzielanie wsparcia, kończenie zajęć. Podobnie M.S. Corey i G. Corey ${ }^{19}$ wymieniają takie umiejętności, jak: aktywne słuchanie, odzwierciedlanie, klaryfikacja, podsumowywanie, konfrontowanie pełne uwagi i troski, wspieranie, diagnozowanie, naprowadzanie/sugerowanie, ewaluacja, empatia, interpretowanie, zadawanie pytań, modelowanie, inicjowanie. Inne wymienione przez tych autorów umiejętności przydatne w pracy grupowej to: wspomaganie rozwoju procesu grupowego, znajdowanie wspólnych mianowników (nacisk na komunikacje między uczestnikami łączenie wypowiedzi jednej osoby z wypowiedziami innego członka grupy), blokowanie niepożądanych zachowań w grupie, kończenie pracy. Sami autorzy za specyficzne umiejętności odnoszące się ściśle do pracy grupowej uznali umiejętność: otwierania i zamykania sesji grupowej, modelowania odpowiednich zachowań $\mathrm{w}$ grupie, otwierania się $\mathrm{w}$ grupie $\mathrm{w}$ adekwatny sposób, udzielania i przyjmowania informacji zwrotnych, pomagania uczestnikom $\mathrm{w}$ nadaniu znaczenia temu, czego doświadczyli w grupie oraz zintegrowania i zastosowania $\mathrm{w}$ życiu tego, czego się $\mathrm{w}$ grupie nauczyli. Zdaniem autorów, najlepszym sposobem doskonalenia tych umiejętności jest praktyka pod superwizją.

J. Strykowska wymienia natomiast umiejętności: komunikacyjne, związane z prowadzeniem grup i diagnostyczne ${ }^{20}$.

Zgodnie ze standardami kwalifikacji zawodowych socjoterapeuty, opracowanymi przez Sekcję Socjoterapii Polskiego Towarzystwa Psychologicznego, w obszarze umiejętności znalazły się: diagnozowanie socjoterapeutyczne, planowanie i projektowanie sytuacji korekcyjnych, prowadzenie zajęć z grupą na podstawie znajomości procesu grupowego, stosowanie zasad komunikacji interpersonalnej, dokonywanie wglądu w siebie, kontakt z własnymi emocjami, trudnościami i motywacją, analizowanie własnej pracy, współpraca z zespołem, budowanie dobrych relacji z innymi, umiejętność rozwiązywania konfliktów ${ }^{21}$.

${ }^{19}$ M.S. Corey, G. Corey, Grupy. Metody grupowej pomocy psychologicznej.

${ }^{20} \mathrm{~J}$. Strykowska, Kompetencje socjoterapeutyczne.

${ }^{21} \mathrm{http}: / /$ www.ptp.org.pl/modules.php?name=News\&file=article\&sid=394， [dostęp: 28.03.2015]. 


\section{Wykształcenie prowadzących grupy socjoterapeutyczne, szkolenia i rozwój własny}

J. Jagieła 22 podaje, że o kompetencjach socjoterapeuty świadczy odpowiednie wykształcenie i kwalifikacje. Wyznacznikiem właściwego wykształcenia akademickiego socjoterapeuty będzie dyplom wyższej uczelni w zakresie psychologii, pedagogiki, socjologii lub innej bardzo zbliżonej do tych dziedzin dyscypliny. Wykształcenie to musi jednak być uzupełnione kilkuletnim szkoleniem $\mathrm{w}$ zakresie terapii. Istotna jest także, zdaniem tego autora, praca zgodnie $\mathrm{z}$ określonym paradygmatem, który tworzy spójny model rozumienia człowieka oraz dynamikę powstawania zaburzeń i sposób terapeutycznych interwencji. Kolejnym elementem kompetencji zawodowych jest superwizja. Uczestnictwo w niej jest dowodem odpowiedzialności i rzetelności profesjonalnego socjoterapeuty. Terapię własną autor ten nie traktuje jako wymogu bezwzględnego, lecz jako sytuację pożądaną i godną zalecenia, szczególnie biorąc pod uwagę fakt, że każda praca terapeutyczna wiąże się z dużymi obciążeniami psychicznymi.

Zdaniem J. Strykowskiej23, właściwa wiedza stanowi podbudowę działań socjoterapeutycznych. Prowadzący grupy powinni charakteryzować się, zdaniem tej autorki, wiedzą z kilku obszarów psychologii i pedagogiki, czyli wiedzą z zakresu: założeń socjoterapii, socjoterapeutycznych mechanizmów zmian, planowania grupowych spotkań terapeutycznych. Istotna jest także wiedza psychologiczna, szczególnie z psychologii rozwojowej i klinicznej, jak również dotycząca takich zachowań charakterystycznych dla rozwoju niedostosowania społecznego, jak: wagarowanie, agresja, nieposłuszeństwo, ucieczki z domu, postawa kłamliwości, używanie alkoholu i narkotyków. Kolejny obszar obejmują zagadnienia dotyczące funkcjonowania rodzin, w szczególności niewydolnych wychowawczo i dysfunkcyjnych. Jako że socjoterapia stanowi pracę z grupą i wobec niej, konieczna jest dlatego wiedza na temat funkcjonowania małych grup. W jej skład wchodziłyby informacje o: procesach, dynamice i sile grupy oraz fazach jej rozwoju. Istotna byłaby także wiedza odnośnie grup społecznych, w których młodzi podopieczni mogą funkcjonować, mianowicie o subkulturach młodzieżowych.

M.S. i G. Coreyowie ${ }^{24}$ pisząc o kompetencjach zawodowych osób prowadzących grupy, zwracają uwagę na posiadanie formalnych uprawnień, np. z psychologii, oraz podkreślają znaczenie kursów dotyczących teorii i praktyki poradnictwa grupowego. Autorzy ci odnosząc się do standardów ASGW (Association of Specialists in Group Work) uznają, że istnieją pewne

\footnotetext{
22 J. Jagieła, Socjoterapia w szkole.

23 J. Strykowska, Kompetencje socjoterapeutyczne.

${ }^{24}$ M.S. Corey, G. Corey, Grupy. Metody grupowej pomocy psychologicznej.
} 
obszary wiedzy podstawowej w przygotowaniu osób prowadzących wszelkiego rodzaju grupy. Obejmują one: znajomość własnych mocnych i słabych stron, świadomość własnego systemu wartości, umiejętność scharakteryzowania typowych stadiów rozwoju grupy, umiejętność opisania konstruktywnych i destruktywnych ról oraz zachowań członków grupy, znajomość czynników terapeutycznych działających $\mathrm{w}$ grupie, rozumienie znaczenia wyników całej grupy i poszczególnych uczestników oraz świadomość kwestii etycznych specyficznych dla pracy $\mathrm{z}$ grupą. Zdaniem tych autorów, uzupełnieniem programu szkolenia dla trenerów grup powinno być odbycie własnej psychoterapii, udział $\mathrm{w}$ treningu terapeutycznym oraz uczestnictwo w grupie superwizyjnej.

I. Yalom ${ }^{25}$ pisząc o szkoleniu psychoterapeutów grupowych, uznaje poza dydaktyką - następujące niezbędne elementy dotyczące treningu psychoterapeutycznego: obserwację pracy doświadczonych klinicystów (przez lustro weneckie, nagrania sesji lub bezpośrednio), superwizję, własne doświadczenie grupowe, psychoterapię własną.

Zgodnie ze standardami kwalifikacji zawodowych socjoterapeuty, opracowanymi przez Sekcję Socjoterapii Polskiego Towarzystwa Psychologicznego ${ }^{26}, \mathrm{w}$ obszarze wiedzy znalazły się: teoria socjoterapii, podstawy pedagogiki i psychologii rozwojowej (potrzeby dzieci na różnych etapach rozwoju), podstawy psychologii ogólnej, mechanizmy uzależnień, struktura i organizacja systemu pomocy dziecku i rodzinie (edukacyjnej, socjalnej i zawodowej), fazy rozwoju grupy i zjawiska w niej zachodzące, przyczyny i objawy zaburzeń w zachowaniu dzieci. Uznano także za niezbędne posiadanie wykształcenia wyższego w stopniu magistra.

\section{Kompetencje socjoterapeutów}

Ze względu na specyfikę pracy socjoterapeuty, polegającą na psychopedagogicznej pomocy grupowej skierowanej do dzieci i młodzieży z grup ryzyka lub doświadczających problemów w funkcjonowaniu społecznym, można wyróżnić pięć podstawowych obszarów kompetencji, istotnych w skutecznym wykonywaniu zawodu. Są to kompetencje: 1) psychologiczno-pedagogiczne, 2) diagnostyczne, 3) pomocy grupowej, 4) autoedukacyjne i 5) moralne. Kompetencje te nie są rozłączne, lecz wzajemnie się uzupełniają. Istnieją również inne kompetencje przydatne $\mathrm{w}$ pracy $\mathrm{z}$ grupą $\mathrm{w}$ socjoterapii, bardziej specyficzne $\mathrm{w}$ określonym kontekście instytucjonalnym (jak

${ }^{25}$ I. Yalom, M. Leszcz, Psychoterapia grupowa. Teoria i praktyka, Kraków 2006.

${ }^{26} \mathrm{http}: / /$ www.ptp.org.pl/modules.php?name=News\&file=article\&sid=394， [dostęp: 28.03.2015]. 
np. placówka resocjalizacyjna lub oświatowa) oraz w odniesieniu do specyficznych problemów, z jakimi borykają się podopieczni, lub ich wieku, których omówienie wykracza poza ramy tej pracy. Należy więc podkreślić, że zaproponowane kompetencje nie stanowią jedynego ani wyczerpującego zestawu. Ma on charakter otwarty - można go rozwijać, modyfikować, uzupełniać, wzbogacać. Nie mają również charakteru rozłącznego. Niektóre umiejętności zaliczane do jednej grupy kompetencji występują w pewnym zakresie także w innej. Przedstawiony zestaw jest podziałem umownym, ale pozwalającym lepiej i dokładniej przeanalizować różne aspekty pracy socjoterapeuty ${ }^{27}$.

Kompetencje psychologiczno-pedagogiczne - uwzględniają posiadanie określonego wykształcenia, które obejmuje wiedzę z dziedziny pedagogiki i psychologii. Szczególnie istotne (choć oczywiście niewystarczające) są zagadnienia będące treścią: psychologii rozwoju człowieka, psychologii klinicznej, pedagogiki społecznej, pedagogiki resocjalizacyjnej, metod pracy z dziećmi i młodzieżą oraz, oczywiście, socjoterapii.

Analizy teoretyczne oraz prowadzone badania $\mathrm{z}$ zakresu socjoterapii mogą dostarczyć prowadzącym grupy informacji przyczyniających się do dobrej praktyki zawodowej, poszerzając ich wiedzę na temat różnych aspektów pracy socjoterapeutycznej. Należy jednak przyznać, że badania naukowe prowadzone $\mathrm{w}$ tym obszarze nie są na razie zbyt liczne, stąd jeszcze większa potrzeba uzupełniania wiedzy o inne dziedziny, aby umożliwić jej wykorzystanie $\mathrm{w}$ pracy grupowej z dziećmi i młodzieżą. Należy także podkreślić, że wybrane aspekty wiedzy z pedagogiki i psychologii są przydatne nie tylko w celu rozumienia funkcjonowania uczestników grupy, ale także wykorzystywane $\mathrm{w}$ omawianych $\mathrm{z}$ grupą zagadnieniach. Różne aspekty funkcjonowania intra- i interpersonalnego są bowiem treścią zajęć socjoterapeutycznych, realizując tym samym cele edukacyjne tej formy pomocy ${ }^{28}$.

Wiedza z psychologii rozwoju człowieka pozwala na właściwe rozeznanie $\mathrm{w}$ prawidłowościach rozwojowych uczestników socjoterapii będących $w$ trakcie dynamicznego rozwoju biopsycho-społecznego. Dzieci i młodzież trafiające oraz uczestniczące $\mathrm{w}$ socjoterapii dotykają kryzysy rozwojowe, związane z podejmowaniem kolejnych zadań rozwojowych i przechodzeniem przez fazy rozwoju psychospołecznego, które stawiają przed nimi no-

27 Zaproponowany sposób rozumienia kompetencji koresponduje z opisem kompetencji nauczycielskich Strykowskiego. Patrz: W. Strykowski, Kompetencje wspótczesnego nauczyciela, Neodidagmata, 2005, 27/28, s. 15-28.

${ }^{28} \mathrm{~W}$ tym rozumieniu omawiane kompetencje można przyrównać do kompetencji merytorycznych nauczycieli wyróżnionych przez W. Strykowskiego: tamże. 
we wymagania $\mathrm{w}$ relacji do dotychczasowych standardów i dążeń Ja ${ }^{29}$. Jakość realizacji zadań rozwojowych w danym momencie życia zależy z jednej strony od zasobów jednostki, a z drugiej od tego jakie wyzwania stawia przed nią otoczenie społeczne $\mathrm{i}$ jakiego wsparcia udziela $\mathrm{w}$ zmaganiu $\mathrm{z}$ nim $^{30}$. Kompetencje socjoterapeuty $\mathrm{w}$ tym obszarze pozwolą na umiejętne towarzyszenie $\mathrm{w}$ rozwoju oraz rozumienie zachowań uczestnika w kontekście rozwojowym ${ }^{31}$.

Wiedza z psychologii klinicznej pozwala na właściwe rozeznanie w problemach psychopatologicznych uczestników grup. W literaturze przedmiotu w odniesieniu do zaburzeń osób kwalifikowanych do socjoterapii wymienia się głównie problemy w zachowaniu i niektóre zaburzenia emocjonalne ${ }^{32}$. Ujmowane są one często $\mathrm{w}$ terminach zaburzeń psychicznych, zaburzeń zachowania, bądź zaburzeń rozwoju, posługując się klasyfikacjami psychiatrycznymi, takimi jak na przykład ICD-10. Opisywanie problemów uczestników w terminach psychopatologicznych powinno opierać się na właściwym wykształceniu (jak np. psychologia kliniczna, psychiatria, szkolenia podyplomowe z psychologii klinicznej lub psychoterapii) i wynikającej $\mathrm{z}$ tego znajomości kategorii diagnostycznych. $\mathrm{W}$ innym przypadku warto mieć na uwadze, że diagnoza wyrażona w języku jednostki nozologicznej jest potoczną (nieprofesjonalną) próbą klasyfikacji33.

Pedagogika społeczna dostarcza wiedzy o środowiskowych uwarunkowaniach procesów wychowawczych i problemach wychowania. Informacje o roli określonych środowisk wychowawczych w kształtowaniu jednostkowej biografii są niezwykle istotne zarówno z punktu widzenia czynników ryzyka powstawania zaburzeń, jak i zasobów jednostkowych oraz społecznych. Rodzina, szkoła i grupa rówieśnicza to trzy rodzaje środowisk społecznych wywierających wpływ na rozwój psychospołeczny dziecka, których oddziaływanie może przyczynić się zarówno do kształtowania właściwych wzorców zachowań społecznych, jak też do nieprzystosowania społecznego jednostki ${ }^{34}$. Na przykład, w literaturze szeroko opisywane są przyczyny powstawania zaburzeń psychicznych w okresie dzieciństwa

${ }^{29}$ E. Erikson, Tożsamość a cykl życia, Poznań 2000.

${ }^{30}$ A. Brzezińska, Spoteczna psychologia rozwoju, Warszawa 2000.

31 Zob. więcej: B. Jankowiak, E. Soroko, Problematyka wsparcia w socjoterapii - wybrane zagadnienia, Studia Edukacyjne, 2014, 32.

32 J. Jagieła, Socjoterapia w szkole.

${ }_{33}$ Zob. więcej: B. Jankowiak, E. Soroko, Wybrane problemy diagnozy opisowej w socjoterapii aspekty teoretyczne oraz zwiazki z funkcjonowaniem zawodowym socjoterapeutów, Studia Edukacyjne, 2014, 33.

${ }^{34}$ L. Pytka, T. Zacharuk, Wielowymiarowa geneza zaburzeń przystosowania społecznego, [w:] Pedagogika spoteczna, red. T. Pilch, I. Leparczyk, Warszawa 1995, s. 396-417. 
i adolescencji ${ }^{35}$ oraz problemów $\mathrm{w}$ funkcjonowaniu społecznym ${ }^{36}$ dzieci wychowywanych w rodzinach, w których występuje alkoholizm lub przemoc ${ }^{37}$.

Wiedza z zakresu pedagogiki resocjalizacyjnej to obszar analiz naukowych dotyczący wychowania osób z zaburzeniami w procesie socjalizacji, np. nieprzystosowanych społecznie, podejmujących zachowania paraprzestępcze i przestępcze. Jednostki wadliwie zsocjalizowane przejawiają wiele zachowań uznawanych za niewłaściwe, niepożądane lub szkodliwe społecznie i indywidualnie ${ }^{38}$. Socjoterapia jest jedną $\mathrm{z}$ wielu możliwych do zastosowania procedur zmiany zachowania, którą przy znajomości zasad prowadzenia zajęć grupowych, metod i technik socjoterapeutycznych można z powodzeniem wykorzystywać w pracy resocjalizacyjnej ${ }^{39}$.

Wiedza o metodach i technikach możliwych do wykorzystania w socjoterapii, takich jak np. choreoterapia, muzykoterapia, terapia zabawą, może przyczynić się do realizacji celów socjoterapeutycznych, wykorzystując podstawową i naturalną predyspozycję $\mathrm{u}$ dzieci związaną $\mathrm{z}$ podejmowaniem interakcji ze światem zewnętrznym poprzez zabawę ${ }^{40}$. Socjoterapia jest także dobrym miejscem, w którym może rozwijać się twórczość dzieci, jako że zajęcia zorientowane są na rozwój uczestników. Promowanie twórczej postawy jest sposobem na autonomiczne i elastyczne wykorzystywanie zasobów uczestników do osiągania celów terapii grupowej ${ }^{41}$. Podstawową techniką wykorzystywaną $\mathrm{w}$ socjoterapii jest jednak praca $\mathrm{w}$ kręgu i rundki zwrotne jako sposób dzielenia się z innymi swoimi doświadczeniami. Krąg ma znaczenie symboliczne, pokazując łączącą wszystkich uczestników wspólnotęe 2 .

Kompetencje diagnostyczne - dotyczą szerokiej gamy umiejętności i wiedzy pozwalających na właściwe rozeznanie zarówno w problemach

${ }^{35}$ Np. P.C. Kendall, Zaburzenia okresu dzieciństwa i adolescencji. Techniki terapeutyczne dla profesjonalistów i rodziców, Sopot 2015.

36 L. Pytka, T. Zacharuk, Wielowymiarowa geneza zaburzeń, s. 396-417.

37 Zob. także: B. Jankowiak, Przeciwdziałanie skutkom nierówności społecznych w pracy socjoterapeutycznej z dziećmi i młodzieża - wybrane zagadnienia, [w:] Edukacja i nierówność. Trajektorie sukcesu i marginalizacji, red. M.J. Szymański, A. Gromkowska-Melosik, Poznań 2014.

38 Pytka L., Pedagogika resocjalizacyjna. Wybrane zagadnienia teoretyczne, diagnostyczne i metodyczne, Warszawa 2008.

${ }^{39}$ E. Silecka, Wybrane konteksty socjoterapii w pracy z jednostkami niedostosowanymi społecznie, [w:] Socjoterapia jako forma pomocy psychologiczno-pedagogicznej; K. Sawicka, Terapia w resocjalizacji, [w:] Resocjalizacja, red. B. Urban, J.M. Stanik, Warszawa 2008.

${ }^{40}$ Zob. także: C. Springer, J.R. Misurell, Game-Based Cognitive-Behavioral Therapy (GB-CBT): An Innovative Group Treatment Program for Children Who Have Been Sexually Abused. Practice Issues, Journal of Child and Adolescent Trauma, 2010, 3, s. 163-180.

${ }^{41}$ Zob. więcej: J. Enko, Twórczość w socjoterapii, [w:] Socjoterapia jako forma pomocy psychologiczno-pedagogicznej.

42 J. Jagieła, Socjoterapia w szkole. 
uczestników grup (co jest niezbędne w kwalifikacji do tej formy pomocy), jak również ocenę procesów grupowych zachodzących podczas zajęć i ewaluację prowadzonej pomocy.

Diagnozę w socjoterapii warto rozumieć wielowymiarowo, podkreślając w szczególności: 1) diagnozę kwalifikującą osobę do tej formy pomocy, 2) diagnozę sytuacji psychologicznej uczestnika, prowadzoną zarówno opisowo, jak i na poziomie wyjaśniającym (próbując uchwycić patomechanizm funkcjonowania oraz czynniki etiopatogenetyczne, a także salutogenetyczne), 3) diagnozowanie procesów grupowych $\mathrm{z}$ uwzględnieniem funkcjonowania interpersonalnego poszczególnych uczestników oraz 4) pojawiającą się na różnych etapach ewaluację postępowania pomocowego na poziomie grupowym oraz indywidualnym ${ }^{43}$.

Szczególne miejsce w kompetencjach diagnostycznych należy przypisać diagnozie dynamiki grupowej. Proces grupowy stanowi całokształt zmieniających się relacji między oddziałującymi na siebie jednostkami - uczestnikami grupy oraz prowadzącymi. Badanie dynamiki grupowej ma w psychologii i pedagogice długą tradycję. Generalnie można wyróżnić dwa podejścia do pomiaru - obserwacyjny (jawna i ukryta obserwacja, obserwacja uczestnicząca, tradycja identyfikowania interakcji w grupie, np. system Balesa) oraz samoopisowy (głównie tradycja badań za pomocą socjogramu) ${ }^{44}$. Diagnozowanie etapu rozwoju grupy jest ważną kompetencją socjoterapeuty, gdyż pozwala mu dobrać odpowiednie sposoby oddziaływania pomocowego, dzięki rozpoznaniu potencjału pomocowego grupy, który jest funkcją relacji wzajemnych między uczestnikami i między prowadzącym socjoterapię a uczestnikami ${ }^{45}$.

Kompetencje pomocy grupowej - odnoszą się do kilku uzupełniających się obszarów: 1) stosowania interwencji socjoterapeutycznych poprzez uruchamianie określonych czynników pomocowych, 2) wspomagania rozwoju procesu grupowego, 3) stosowania wiedzy i umiejętności pracy z grupą.

Przyjmując założenie, że socjoterapeuta poprzez swoje oddziaływania realizuje nie tylko cele edukacyjne i rozwojowe, ale także terapeutyczne, konieczne jest wyróżnienie intencjonalnie stosowanych czynników mających określone działanie wprowadzania zmian w funkcjonowaniu psychospołecznym uczestników. Myślenie o czynnikach pomocowych zaczerpnięto z idei czynników leczących w psychoterapii. Jednakże w socjoterapii, w od-

${ }^{43}$ B. Jankowiak, E. Soroko, Wybrane problemy diagnozy opisowej w socjoterapii.

${ }^{44}$ B. Jankowiak, E. Soroko, Diagnozowanie procesu grupowego w socjoterapii, [w:] Wspótczesne konteksty psychoterapii $i$ socjoterapii - wybrane zagadnienia $z$ teorii i praktyki, red. K. Waszyńska, M. Filipiak, Poznań 2015 (w druku).

45 Tamże. 
różnieniu od psychoterapii, mniej akcentuje się ich potencjał leczący (zaburzenia psychiczne), a bardziej potencjał edukacyjny, wspierania rozwoju oraz kształtowania umiejętności społecznych ${ }^{46}$. Przyjęto za B. Jankowiak i E. Soroko określenie "czynniki pomocowe" zamiast "czynniki terapeutyczne" lub „czynniki leczące”, ponieważ uruchamiany przez socjoterapeutów proces jest z natury psychopedagogiczny. Dotyczy zarówno aspektu psychologicznego funkcjonowania uczestników grup, jak i obszaru oddziaływań wychowawczych. Trudno bowiem jednoznacznie określić, jak bardzo terapeutyczna (w sensie „lecząca”, korekcyjna względem zaburzeń psychicznych), a jak bardzo rozwojowa (na przykład profilaktyczna lub wspierająca) jest ta interwencja ${ }^{47}$. I. Yalom ${ }^{48}$ wymienia jedenaście głównych czynników leczących występujących w psychoterapii grupowej: zaszczepianie nadziei, uniwersalność, udzielanie informacji, altruizm, korektywne odtworzenie rodziny pierwotnej, rozwój umiejętności społecznych, naśladowanie, uczenie się interpersonalne, spójność grupy, katharsis, czynniki egzystencjalne. M.S. i G. Coreyowie ${ }^{49}$ do czynników działających w grupie zaliczają: otwieranie się przed innymi, konfrontację, informacje zwrotne, spójność i poczucie wspólnoty, nadzieję, gotowość do podejmowania ryzyka i do zaufania, życzliwość, troskę i akceptację, moc osobistą, katharsis, czynnik poznawczy, motywację do zmiany, swobodę eksperymentowania i humor. Czynniki, które dodatkowo wydają się szczególnie powszechne w socjoterapii to: identyfikacja z pozytywnym dorosłym, towarzyszenie w przeżywaniu kryzysów rozwojowych, przestrzeganie zasad i norm obowiązujących $\mathrm{w}$ grupie oraz przekazywanie wartości ${ }^{50}$. Aktywacja odpowiednich czynników pomocowych jest wyrazem kompetencji socjoterapeuty, gdyż może on w ten sposób realizować cele rozwojowe, edukacyjne, jak i terapeutyczne (w szerokim rozumieniu doprowadzania do zmiany $\mathrm{w}$ funkcjonowaniu psychospołecznym). Poprawa funkcjonowania psychospołecznego uczestników socjoterapii wynika więc z planowo kształtowanych lub moderowanych przez socjoterapeutę interakcji pomiędzy prowadzącym a poszczególnymi uczestnikami, pomiędzy uczestnikami między sobą oraz konkretnym uczestnikiem a grupą jako całością51.

${ }^{46}$ Za: B. Jankowiak, E. Soroko, Style socjoterapeutycznej pracy grupowej z dziećmi i młodzieża z perspektywy czynników pomocowych, Studia Edukacyjne, 2014, 31.

47 Tamże.

${ }^{48}$ I. Yalom, M. Leszcz, Psychoterapia grupowa; S. Vinogradov, I. Yalom, Psychoterapia grupowa.

${ }^{49}$ G. Corey, Teoria i praktyka poradnictwa i psychoterapii, Poznań 2005; M.S. Corey, G. Corey, Grupy. Metody grupowej pomocy psychologicznej.

${ }^{50}$ B. Jankowiak, E. Soroko, Czynniki pomocowe w socjoterapii dzieci i młodzieży.

${ }^{51}$ B. Jankowiak, E. Soroko, Style socjoterapeutycznej pracy grupowej z dziećmi i młodzieża. 
Kolejnym aspektem tej grupy kompetencji jest właściwe wspomaganie pracy grupy tak, aby mogła przejść przez kolejne etapy rozwoju procesu grupowego. Stosowana wiedza i umiejętności dotyczą: znajomości zasad pracy grupowej oraz umiejętności zastosowania w praktyce wiedzy o fazach rozwoju grupy, aby we właściwy sposób reagować na pojawiające się sytuacje grupowe oraz oczekiwania członków grupy ${ }^{52}$.

Przyjmując klasyczny podział na cztery fazy rozwoju, wyróżniono fazy: początkową pracy grupy socjoterapeutycznej, eksploracji różnic $\mathrm{w}$ grupie socjoterapeutycznej, konstruktywnej pracy grupy socjoterapeutycznej, zakończenia pracy grupy socjoterapeutycznej ${ }^{53}$. W każdej z nich kompetentna praca socjoterapeutyczna wymaga użycia innych umiejętności prowadzenia grupy, wynikających z wiedzy na temat prawidłowości pracy na tym etapie. Poniżej w tabeli przedstawiono krótką charakterystykę zadań socjoterapeuty w poszczególnych fazach rozwoju grupy ${ }^{54}$.

Tabela 1

Wspomaganie pracy grupy socjoterapeutycznej w przechodzeniu przez kolejne fazy

\begin{tabular}{|c|c|}
\hline Faza & Sposób pracy socjoterapeutycznej \\
\hline $\begin{array}{l}\text { Początkowa } \\
\text { pracy grupy } \\
\text { socjoterapeutycznej }\end{array}$ & $\begin{array}{l}\text { - strukturyzowanie pracy grupy (jako że członkowie grupy } \\
\text { polegają w tej fazie na socjoterapeucie), } \\
\text { - pomoc w integracji poszczególnych członków grupy } \\
\text { z grupą jako całością, } \\
\text { - ustalenie z członkami grupy zasad pracy grupy, }\end{array}$ \\
\hline $\begin{array}{l}\text { Eksploracji różnic } \\
\text { w grupie } \\
\text { socjoterapeutycznej }\end{array}$ & $\begin{array}{l}\text { - pomoc w stawianiu czoła konfliktom poprzez rozpozna- } \\
\text { wanie sytuacji konfliktowych i gruntowne ich przepraco- } \\
\text { wanie, } \\
\text { - uwzględnianie oporu i konstruktywne postępowanie } \\
\text { z jego przejawami, } \\
\text { - modelowanie postaw i zachowań przez otwarte trakto- } \\
\text { wanie wszelkich form krytyki własnej osoby lub funkcjo- } \\
\text { nowania w roli zawodowej, }\end{array}$ \\
\hline $\begin{array}{l}\text { Konstruktywnej } \\
\text { pracy grupy } \\
\text { socjoterapeutycznej }\end{array}$ & $\begin{array}{l}\text { - wspieranie samodzielności uczestników i aktywności } \\
\text { grupy poprzez mniejsze strukturyzowanie pracy grupy } \\
\text { i stosowanie mniej interwencji, }\end{array}$ \\
\hline
\end{tabular}

52 Zob. więcej: B. Jankowiak, E. Soroko, Problematyka wsparcia w socjoterapii.

${ }^{53}$ Określenia faz rozwoju grupy socjoterapeutycznej przyjęto zgodnie z podziałem Tryjarskiej, które wywodzi się z obszaru psychoterapii grupowej: B. Tryjarska, Wprowadzenie. Specyfika psychoterapii grupowej, [w:] Psychoterapia. Praktyka, red. L. Grzesiuk, Warszawa 2006.

54 Więcej na temat wsparcia ukierunkowanego na przechodzenie przez fazy rozwoju grupy w: B. Jankowiak, E. Soroko, Problematyka wsparcia w socjoterapii. 


\begin{tabular}{|l|l|}
\hline \multicolumn{1}{|c|}{ Faza } & \multicolumn{1}{c|}{ Sposób pracy socjoterapeutycznej } \\
\hline Zakończenia & \multicolumn{1}{c|}{ pomoc w radzeniu sobie z uczuciami separacyjnymi, } \\
pocjoterapeutycznej & - pomoc w nadawaniu znaczenia procesom i zdarzeniom \\
& $\begin{array}{l}\text { zachodzącym w grupie, aby uczestnicy nie zdystansowali } \\
\text { się od tych doświadczeń na koniec pracy, }\end{array}$ \\
& - pomoc w uogólnieniu zdobytej wiedzy i umiejętności na \\
& sytuacje z codziennego życia. \\
\hline
\end{tabular}

Źródło: opracowanie własne za: M.S. Corey, G. Corey, Grupy. Metody grupowej pomocy psychologicznej, Warszawa 2002; B. Tryjarska, Wprowadzenie. Specyfika psychoterapii grupowej, [w:] Psychoterapia. Praktyka, red. L. Grzesiuk, Warszawa 2006; B. Jankowiak, E. Soroko, Problematyka wsparcia w socjoterapii - wybrane zagadnienia, Studia Edukacyjne, 2014, 32 .

W odniesieniu do stosowania wiedzy i umiejętności pracy z grupą, w niniejszej pracy omówiono podstawowe zagadnienia poruszane $\mathrm{w}$ literaturze dotyczące tego tematu. W tym miejscu - jako podsumowanie - zaprezentowane zostaną profesjonalne standardy szkolenia trenerów i terapeutów grupowych (ASGW - Association for Specialists in Group Work) w zakresie wiedzy i umiejętności koniecznych do prowadzenia grup terapeutycznych i rozwojowych ${ }^{55}$.

W zakresie wiedzy, każda osoba prowadząca grupy powinna umieć:

- scharakteryzować każdy z czterech głównych typów grup - grupy zadaniowe, trening grupowy, ustrukturalizowane grupy psychoedukacyjne oraz grupy psychoterapeutyczne ${ }^{56}$,

- wyjaśnić podstawowe prawidłowości rządzące dynamiką grupy,

- omówić podstawowe aspekty terapeutyczne sytuacji grupowej,

- określić mocne i słabe strony samego siebie, własne wartości i inne cechy osobowe, które wywierają wpływ na grupę,

- opisać normy etyczne obowiązujące w pracy z grupą,

- omówić trendy badawcze w zakresie pracy z grupą i umieć je odnieść do własnego przygotowania akademickiego,

- opisać cechy charakterystyczne każdej fazy procesu grupowego,

- opisać przykłady ról grupowych oraz typów zachowań uczestników sprzyjających i niesprzyjających osiąganiu celów grupy,

- podać wady i zalety pracy grupowej oraz przykłady sytuacji, w których ta forma oddziaływania terapeutycznego jest właściwa, jak i tych, w których jest niewłaściwa,

- opisać czynniki terapeutyczne działające w pracy grupowej,

55 W cytowanych standardach nie pojawia się słowo „socjoterapia", gdyż taka forma pomocy grupowej jest specyficzna dla polskiej pomocy psychopedagogicznej. Opisywane standardy są jednak uznawane za uniwersalne dla wszystkich profesjonalistów zajmujących się pracą grupową.

56 Ze względu na polską specyfikę stosowanych form pomocy grupowej, socjoterapeuci powinni umieć odróżnić socjoterapię od innych form pomocy. 
- określić strategie rekrutowania i dyskwalifikowania kandydatów do grup,

- rozumieć znaczenie oceny grupy i jej członków.

Osoba prowadząca grupy powinna posiadać zakres niezbędnych umiejętności umożliwiających jej podejmowanie takich działań, jak:

- zachęcanie do uczestnictwa w grupie,

- uważne obserwowanie zachowania i funkcjonowania wszystkich osób w grupie,

- klaryfikowanie i podsumowywanie wypowiedzi uczestników, otwieranie i zamykanie sesji grupowych,

- udzielanie grupie właściwych informacji we właściwym czasie,

- modelowanie zachowań oczekiwanych od uczestników grupy,

- otwieranie się w adekwatny sposób wobec grupy,

- udzielanie i przyjmowanie informacji zwrotnych,

- zadawanie pytań otwartych,

- bycie empatycznym wobec członków grupy,

- w razie potrzeby stosowanie konfrontacji odnoszącej się do zachowań uczestników,

- pomaganie uczestnikom grupy w uświadamianiu sobie, jakie znaczenie ma dla nich to, czego doświadczyli w grupie,

- pomaganie uczestnikom $\mathrm{w}$ integrowaniu procesu uczenia się $\mathrm{w}$ grupie i stosowaniu w życiu tego, czego się uczą,

- stosowanie w pracy grupowej profesjonalnych norm etycznych,

- utrzymywanie kierunku pracy sprzyjającego osiąganiu celów grupy ${ }^{57}$.

Kompetencje autoedukacyjne. Ustawiczne kształcenie i samodoskonalenie stanowi wiodącą ideę współczesnej edukacji ${ }^{58}$. Kompetencje te związane są z samokształceniem, ciągłym podwyższaniem kwalifikacji, doskonaleniem własnego warsztatu pracy ${ }^{59}$. Idea ustawicznego kształcenia jest niezwykle ważna $\mathrm{w}$ odniesieniu do zawodów, w których osobowość jest swoistym narzędziem pracy - jak ma to miejsce $w$ pracy $w$ obszarze pomocy

${ }^{57}$ M.S. Corey, G. Corey, Grupy. Zasady i techniki grupowej pomocy psychologicznej, Warszawa 1995, s. 73-74. Zob. także: http://www.asgw.org/pdf/training_standards.pdf, [dostęp: 07.04.2015].

58 W. Strykowski, Kompetencje wspótczesnego nauczyciela, s. 15.

59 Tę grupę kompetencji Strykowski zalicza (za S. Dylakiem) do kompetencji pożądanych w zawodzie nauczyciela, które budują jego prestiż, a także pozwalają skuteczniej realizować zadania dydaktyczne i wychowawcze. W odniesieniu do zawodu socjoterapeuty wydaje się, że wiele z omówionych umiejętności składających się na kompetencje autoedukacyjne stanowią kompetencje konieczne (np. superwizowanie własnej pracy terapeutycznej). Oznacza to, że bez nich osoby uprawiające zawód socjoterapeuty nie mogłyby skutecznie wypełniać celów socjoterapii. Tamże. 
psychopedagogicznej. Kompetencje autoedukacyjne socjoterapeutów omawiane będą $\mathrm{w}$ kilku obszarach: 1) szkolenia $\mathrm{w}$ zakresie pracy $\mathrm{z}$ grupą, 2) szkolenia zgodnie $z$ wybranym paradygmatem rozumienia człowieka, 3) superwizji własnej pracy socjoterapeutycznej.

M.S. i G. Coreyowie pisząc o standardach szkolenia zawodowego trenerów i terapeutów grupowych, powołują się na standardy ASGW (Association for Specialists in Group Work). Jako podstawę pracy zawodowej przyjmują kurs umożliwiający zdobycie podstawowej wiedzy i umiejętności potrzebnych do prowadzenia grupy. Podkreślają, że rozwijaniu tych umiejętności najlepiej służy praktyka odbywana pod superwizją, obejmująca obserwacje $\mathrm{i}$ bezpośrednie uczestnictwo $\mathrm{w}$ grupie. Kolejne etapy szkolenia uwzględniają specjalizacje $\mathrm{w}$ prowadzeniu jednego lub więcej $\mathrm{z}$ czterech następujących typów grup: zadaniowe/robocze, psychoedukacyjne, treningowe, psychoterapeutyczne ${ }^{60}$. M.S. i G. Coreyowie nie odnoszą się do prowadzenia grup socjoterapeutycznych, gdyż ta grupowa forma pomocy jest specyficzna dla polskiej pomocy grupowej. Przeplatają się w niej oddziaływania charakterystyczne zarówno dla treningu interpersonalnego, psychoedukacji, jak i psychoterapii ${ }^{61}$. Wymienieni autorzy jako uzupełnienie programu szkolenia rekomendują trzy rodzaje doświadczeń: psychoterapię własną dla prowadzącego grupę, grupy samopoznania (grupowy trening terapeutyczny), grupy superwizyjne ${ }^{62}$.

Szkolenie zgodnie $\mathrm{z}$ wybranym paradygmatem rozumienia człowieka jest niezwykle istotne dla własnego rozwoju socjoterapeutów, wzbogacając ich możliwości funkcjonowania $\mathrm{w}$ roli zawodowej. Jednakże, w praktyce pracy socjoterapeutycznej, w odróżnieniu od psychoterapii, rzadko stosuje się zasadę jedności paradygmatycznej, która wyznacza spójny model rozumienia funkcjonowania wspomaganego. Zdaniem J. Jagieły, podejście socjoterapeutyczne obecnie nie tworzy spójnego i jednoznacznego podejścia terapeutycznego. Mamy tu do czynienia z pewną różnorodnością ujęć, składającą się na rozwiązania o charakterze eklektycznym. Najczęściej, $\mathrm{w}$ zależności od przebytego przez danego socjoterapeutę typu szkolenia, skłania się on w kierunku któregoś z istniejących kierunków pracy terapeutycznej63. Należy jednak podkreślić, że przyjęcie określonej teorii rozumienia człowieka i powstawania zaburzeń daje dużo większą możliwość intencjonalnego stosowania określonych metod pracy oraz interwencji psychologicznych. M. Wilk przedstawia opis rozumienia dylematów uczestników

${ }^{60}$ M.S. Corey, G. Corey, Grupy. Metody grupowej pomocy psychologicznej.

${ }^{61}$ Zob. więcej: B. Jankowiak, E. Soroko, Socjoterapia a inne formy pomocy psychologicznopedagogicznej.

62 M.S. Corey, G. Corey, Grupy. Metody grupowej pomocy psychologicznej.

${ }^{63} \mathrm{~J}$. Jagieła, Socjoterapia w szkole. 
socjoterapii zgodnie z paradygmatem psychodynamicznym, powołując się na psychodynamiczne teorie rozwojowe i spójne z nimi obszary funkcjonowania uczestników grup, istotne dla właściwej diagnozy w socjoterapii ${ }^{64}$. Autor ten podkreśla, że wyłącznie jednoznaczna perspektywa teoretyczna umożliwia socjoterapeucie skuteczną pracę terapeutyczną poprzez odpowiadanie na potrzeby dzieci i młodzieży, nie tylko te zwerbalizowane, ale i niezwerbalizowane - wyłaniające się podczas zajęć, np. poprzez styl funkcjonowania $\mathrm{w}$ grupie ${ }^{65}$. Zdaniem J. Jagieły, paradygmat pracy wyznacza styl pracy terapeutycznej, sposób myślenia na temat spotykanych przypadków, tworzy spójny model rozumienia człowieka oraz dynamikę powstawania zaburzeń i sposób terapeutycznych interwencji66.

Superwizja własnej pracy socjoterapeutycznej jest istotnym elementem podnoszenia kompetencji zawodowych. Stanowi zarówno istotny element kształtowania własnej drogi zawodowej, jak i świadczy o kompetencjach moralnych. J. Jagieła uznaje, że superwizja jest nieodzownym i ważnym elementem ogólnych kwalifikacji socjoterapeuty. Daje możliwość analizy swojej pracy terapeutycznej, własnych reakcji emocjonalnych i poznawczych, podejmowanych interwencji pod okiem bardziej doświadczonego profesjonalisty lub grupy specjalistów. Postępowanie to chroni socjoterapeutę przed nadmiernym subiektywizmem i wpływem własnych deficytów psychologicznych na jakość relacji z uczestnikami zajęćc7. Udział w grupie superwizyjnej prowadzi do wglądu i pogłębienia świadomości68. Zdaniem M. Wilka, superwizja (wraz z jednoznaczną perspektywą teoretyczną) jest wyłącznym gwarantem prowadzenia zajęć $\mathrm{w}$ zgodzie $\mathrm{z}$ potrzebami uczestników ${ }^{69}$.

Kompetencje moralne - wyrażają się w świadomym kierowaniu przez socjoterapeutę wartościami, obyczajami, normami i wzorami postępowania, które stanowią o etosie i specyficznej odrębności społeczno-zawodowej. Zasadami dobrej praktyki zawodowej socjoterapeuta powinien kierować się na każdym etapie kontaktu z uczestnikami grup - zarówno przy kwalifikacji, podczas pracy z grupą oraz po zakończeniu pracy. Zasady etyczne dotyczą także kontaktów z innymi specjalistami, rodzicami oraz z instytucją w jakiej prowadzona jest socjoterapia. Jak podkreślają M.S. i G. Coreyowie, bycie etycznym trenerem i terapeutą grupowym obejmuje więcej niż tylko

\footnotetext{
${ }^{64}$ M. Wilk, Diagnoza w socjoterapii. Ujęcie psychodynamiczne, Sopot 2014.

${ }^{65}$ Tamże, s. 191.

${ }^{66} \mathrm{~J}$. Jagieła, Socjoterapia w szkole.

67 Tamże.

${ }_{68}$ M.S. Corey, G. Corey, Grupy. Metody grupowej pomocy psychologicznej.

${ }^{69}$ M. Wilk, Diagnoza w socjoterapii.
} 
unikanie łamania prawa lub naruszania przepisów kodeksów etycznych. Wymaga wysokiego poziomu świadomości zarówno w zakresie etyki zawodowej, jak i osobistej70.

J. Gumaer i A. Forrest opisali trzy kroki, jakie może poczynić doradca grupowy w celu zadbania o etyczną i prawną stronę swojej praktyki:

- zdobyć wiedzę na temat zawodowych kodeksów etycznych,

- analizować sytuacje grupowe $\mathrm{w}$ aspekcie etycznym i podejmować przemyślane decyzje oparte na profesjonalnych standardach,

- wykazywać zainteresowanie stroną etyczną pracy z grupą podczas superwizji i szkoleń ${ }^{71}$.

Ponieważ omówienie wszystkich zagadnień etycznych, ważnych $\mathrm{w}$ kompetentnej pracy socjoteraputy, wykracza poza ramy tej pracy, odniesiono się wyłącznie do kolejnych faz pracy grupowej, zaznaczając najważniejsze aspekty kompetencji moralnych.

Na etapie kwalifikacji uczestników M.S. i G. Coreyowie, w odniesieniu do zasad etycznych, cytują wskazania etyczne dla doradców grupowych ASGW (Association of Specialists in Group Work), które stanowią, że

$\mathrm{w}$ takim stopniu, $\mathrm{w}$ jakim jest to możliwe [doradca] dobiera do grupy te osoby, których potrzeby i cele są zgodne z celami grupy, które nie będą zakłócały pracy grupy oraz których dobrostan nie będzie narażony na szwank wskutek przebytych $\mathrm{w}$ grupie doświadczeń ${ }^{72}$.

Szczególnie istotne są zagadnienia dotyczące świadomej zgody na uczestnictwo $\mathrm{w}$ grupie. W celu spełnienia tej zasady należy dostarczyć uczestnikom wszelkich informacji o grupie (celach, stosowanych procedurach, technikach, prawie do odmowy udziału w określonych ćwiczeniach, wyjątkach od zasady dyskrecji), aby mogli dokonać świadomego wyboru związanego $\mathrm{z}$ udziałem $\mathrm{w}$ grupie ${ }^{73}$. Jest to problem szczególnie trudny $\mathrm{w}$ grupach niedobrowolnych (np. w placówkach resocjalizacyjnych) ${ }^{74}$. W odniesieniu do młodzieży nieprzystosowanej społecznie kolejnym problemem jest ich wola uczestniczenia $w$ zajęciach socjoterapeutycznych. Tacy młodzi ludzie mogą nie odczuwać potrzeby zmiany, co niezwykle utrudnia pracę pomocową oraz wymaga od socjoterapeuty umiejętności wzbudzenia motywacji do zajęć socjoterapeutycznych. $W$ tych przypadkach socjoterapeuta powinien szczególnie dokładnie wyjaśniać cele grupy oraz potencjalne korzyści uczestniczenia w zajęciach, a jeśli młodzież, ze względu na cha-

\footnotetext{
${ }^{70}$ M.S. Corey, G. Corey, Grupy. Metody grupowej pomocy psychologicznej.

71 Za: tamże.

72 Tamże.

73 Tamże.

${ }^{74}$ E. Silecka, Wybrane konteksty socjoterapii w pracy z jednostkami niedostosowanymi spotecznie.
} 
rakter placówki, jest zobowiązana wziąć w nich udział - umożliwić wyrażanie wszystkich wątpliwości i emocji z tym związanych.

Podczas pracy grupowej, zgodnie $\mathrm{z}$ cytowanymi standardami, w procesie grupowym terapeuta bierze odpowiedzialność za klienta, uwzględniając zabezpieczenie go przed fizyczną, emocjonalną albo psychologiczną krzywdą ${ }^{75}$. W odniesieniu do poufności i ochrony prywatności w pracy grupowej konsultanci grupowi w zrozumiały sposób powinni wyjaśnić znaczenie i zasady poufności $w$ pracy grupowej ${ }^{76}$. Prowadzący grupy powinni wybierać techniki i styl prowadzenia grupy właściwy do typu grupy ${ }^{77}$. W trakcie trwania grupy ważnym aspektem jest prawo uczestników do wycofania się $\mathrm{z}$ grupy - zadaniem socjoterapeuty jest pomóc uczestnikowi w tym, aby uczynił to w sposób efektywny, a zasady odejścia $\mathrm{z}$ grupy powinny być wcześniej ustalone ${ }^{78}$. Zasada dyskrecji jest kolejnym warunkiem efektywnej pracy grupowej. Socjoterapeuta ma za zadanie sam zachować dyskrecję oraz zadbać o zachowanie dyskrecji przez członków grupy. Ważne jest więc podkreślanie znaczenia dyskrecji przez prowadzącego grupę na różnych etapach rozwoju grupy ${ }^{79}$.

W odniesieniu do ewaluacji pracy grupy, prowadzący powinni prowadzić ewaluację działań (zarówno formalną, jak i nieformalną) pomiędzy sesjami oraz na zakończenie pracy grupy ${ }^{80}$. Prowadzący grupy oceniają zarówno proces, jak i wyniki. Uzyskane dane mogą być używane zarówno do oceny toczącego się procesu, planowania, poprawy i korekty pracy z obecną grupą, jak też do wzbogacenia wiedzy fachowej poprzez publikacje w literaturze naukowej ${ }^{81}$. Prowadzący grupy zobowiązani są także do utrzymywania dalszego kontaktu z członkami grupy, aby ocenić wyniki pracy grupy albo na prośbę członka/członków grupy ${ }^{82}$.

W niniejszej pracy poddano analizie znaczenie prowadzącego socjoterapię - zarówno jako osoby, jak i specjalisty - dla efektywnej pracy grupowej. Charakterystyka roli zawodowej, posiadana wiedza, umiejętności i przyjmowane postawy przekładają się na efektywność pracy. Celem artykułu było przedstawienie różnych obszarów kompetencji, istotnych w pracy so-

${ }^{75}$ http://www.counseling.org/resources/aca-code-of-ethics.pdf, [dostęp: 7.04.2015].

76 Tamże.

77 R.V. Thomas, D.A. Pender, Association for Specialists in Group Work: Best Practice Guidelines 2007 Revisions, http://www.asgw.org/pdf/Best_Practices.pdf, [dostęp: 7.04.2015].

${ }_{78}$ M.S. Corey, G. Corey, Grupy. Metody grupowej pomocy psychologicznej.

${ }^{79}$ Por. tamże.

${ }^{80}$ R.V. Thomas, D.A. Pender, Association for Specialists in Group Work.

81 Przestrzegając standardów używania zdobytego materiału dla badań i raportów naukowych.

82 R.V. Thomas, D.A. Pender, Association for Specialists in Group Work. 
cjoterapeutycznej. Za najważniejsze - choć, co należy podkreślić, uzupełniające się, nierozłączne i niejedyne - uznano kompetencje: 1) psychologicznopedagogiczne, 2) diagnostyczne, 3) pracy grupowej, 4) autoedukacyjne, 5) moralne. Wyróżnienie tych kompetencji umożliwiło dokonanie charakterystyki zawodowej kompetentnego socjoterapeuty.

\section{BIBLIOGRAFIA}

Bartkowicz Z., Kształtowanie świadomości aksjologicznej pedagogów resocjalizacyjnych, [w:] Powinności i kompetencje w wychowaniu osób niedostosowanych spotecznie, red. Z. Bartkowicz, A. Węgliński, A. Lewicka, Wydawnictwo UMCS, Lublin 2010.

Brzezińska A., Społeczna psychologia rozwoju, Wydawnictwo Naukowe Scholar, Warszawa 2000.

Corey G., Teoria i praktyka poradnictwa i psychoterapii, Wydawnictwo Zysk i S-ka, Poznań 2005.

Corey M.S., Corey G., Grupy. Zasady i techniki grupowej pomocy psychologicznej, IPZiT, Warszawa 1995.

Corey M.S., Corey G., Grupy. Metody grupowej pomocy psychologicznej, Instytut Psychologii Zdrowia, Warszawa 2002.

Czerepaniak-Walczak M., Między dostosowaniem a zmianą. Elementy emancypacyjnej teorii edukacji, Wydawnictwo Naukowe US, Szczecin 1995.

Czerepaniak-Walczak M., Aspekty i źródła profesjonalnej refleksji nauczyciela, Wydawnictwo Edytor, Torun 1997.

Enko J., Twórczość w socjoterapii, [w:] Socjoterapia jako forma pomocy psychologicznopedagogicznej. Teoria i praktyka, red. B. Jankowiak, Wydawnictwo Naukowe UAM, Poznań 2013.

Erikson E., Tożsamość a cykl życia, Dom Wydawniczy Rebis, Poznań 2000.

http://www.counseling.org/resources/aca-code-of-ethics.pdf, [dosteep: 7.04.2015]

http://www.ptp.org.pl/modules.php?name=News\&file=article\&sid=394, [dostęp: 28.03. 2015].

Jagieła J., Socjoterapia w szkole. Krótki poradnik psychologiczny, Wydawnictwo Rubikon, Kraków 2007.

Jankowiak B., Przeciwdziatanie skutkom nierówności społecznych w pracy socjoterapeutycznej $z$ dziećmi i młodzieża - wybrane zagadnienia, [w:] Edukacja i nierówność. Trajektoria sukcesu i marginalizacji, red. M.J. Szymański, A. Gromkowska-Melosik, Wydawnictwo Naukowe UAM, Poznań 2014.

Jankowiak B., Soroko E., Czynniki pomocowe w socjoterapii dzieci i młodzieży - refleksja teoretyczna [w:] Socjoterapia jako forma pomocy psychologiczno-pedagogicznej. Teoria i praktyka, red. B. Jankowiak, Wydawnictwo Naukowe UAM, Poznań 2013.

Jankowiak B., Soroko E., Socjoterapia a inne formy pomocy psychologiczno-pedagogicznej, [w:] Socjoterapia jako forma pomocy psychologiczno-pedagogicznej. Teoria $i$ praktyka, red. B. Jankowiak, Wydawnictwo Naukowe UAM, Poznań 2013.

Jankowiak B., Soroko E., Style socjoterapeutycznej pracy grupowej z dziećmi i młodzieża z perspektywy czynników pomocowych, Studia Edukacyjne, 2014, 31.

Jankowiak B., Soroko E., Problematyka wsparcia w socjoterapii - wybrane zagadnienia, Studia Edukacyjne, 2014, 32. 
Jankowiak B., Soroko E., Wybrane problemy diagnozy opisowej w socjoterapii - aspekty teoretyczne oraz zwiąki z funkcjonowaniem zawodowym socjoterapeutów, Studia Edukacyjne, $2014,33$.

Jankowiak B., Soroko E., Diagnozowanie procesu grupowego w socjoterapii, [w:] Wspótczesne konteksty psychoterapii $i$ socjoterapii - wybrane zagadnienia $z$ teorii i praktyki, red. K. Waszyńska, M. Filipiak, Wydawnictwo Naukowe UAM, Poznań 2015 (w druku).

Kendall P.C., Zaburzenia okresu dzieciństwa $i$ adolescencji. Techniki terapeutyczne dla profesjonalistów i rodziców, Gdańskie Wydawnictwo Psychologiczne, Sopot 2015.

Kubacka-Jasiecka D., Interwencja kryzysowa, Wydawnictwa Akademickie i Profesjonalne, Warszawa 2010.

Opora R., Resocjalizacja: wychowanie i psychokorekcja nieletnich nie dostosowanych społecznie, Oficyna Wydawnicza Impuls, Kraków 2010.

Pytka L., Pedagogika resocjalizacyjna. Wybrane zagadnienia teoretyczne, diagnostyczne i metodyczne, Wydawnictwo Pedagogiki Specjalnej, Warszawa 2008.

Pytka L., Zacharuk T., Wielowymiarowa geneza zaburzeń przystosowania społecznego, [w:] Pedagogika społeczna, red. T. Pilch, I. Leparczyk, Wydawnictwo Akademickie Żak, Warszawa 1995, s. 396-417.

Sawicka K., Terapia w resocjalizacji, [w:] Resocjalizacja, red. B. Urban, J.M. Stanik, Wydawnictwo Naukowe PWN, Warszawa 2008.

Silecka E., Wybrane konteksty socjoterapii w pracy z jednostkami niedostosowanymi spotecznie, [w:] Socjoterapia jako forma pomocy psychologiczno-pedagogicznej. Teoria i praktyka, red. B. Jankowiak, Wydawnictwo Naukowe UAM, Poznań 2013.

Springer C., Misurell J.R., Game-Based Cognitive-Behavioral Therapy (GB-CBT): An Innovative Group Treatment Program for Children Who Have Been Sexually Abused. Practice Issues, Journal of Child and Adolescent Trauma, 2010, 3.

Strykowska J., Kompetencje socjoterapeutyczne w pracy pedagogicznej, Neodidagmata, 2011, $31 / 32$.

Strykowski W., Kompetencje wspótczesnego nauczyciela, Neodidagmata, 2005, 27/28.

Strykowski W., Szkoła współczesna i zachodzące w niej procesy, [w:] Kompetencje nauczyciela szkoty wspótczesnej, red. W. Strykowski, J. Strykowska, J. Pielachowski, Wydawnictwo EMPI2 Oficyna Ekonomiczna, Poznań 2007.

Thomas R.V., Pender D.A., Association for Specialists in Group Work: Best Practice Guidelines 2007 Revisions, http://www.asgw.org/pdf/Best_Practices.pdf, [dostęp: 7.04.2015].

Tryjarska B., Wprowadzenie. Specyfika psychoterapii grupowej, [w:] Psychoterapia. Praktyka, red. L. Grzesiuk, Wydawnictwo ENETEIA, Warszawa 2006.

Vinogradov S., Yalom I., Psychoterapia grupowa. Krótki przewodnik dla terapeutów, Instytut Psychologii Zdrowia PTP, Warszawa 2007.

Waszyńska K., Socjoterapeuta: osoba i specjalista. Kompetencje $i$ kwalifikacje socjoterapeuty, [w:] Socjoterapia jako forma pomocy psychologiczno-pedagogicznej. Teoria $i$ praktyka, red. B. Jankowiak, Wydawnictwo Naukowe UAM, Poznań 2013.

Wilk M., Diagnoza w socjoterapii. Ujęcie psychodynamiczne, Gdańskie Wydawnictwo Psychologiczne, Sopot 2014.

Yalom I., Leszcz M., Psychoterapia grupowa. Teoria i praktyka, Wydawnictwo UJ, Kraków 2006. 